\author{
MARGARITA HANHAUSEN COLE \\ UNIVERSIDAD IBEROAMERICANA
}

\title{
Una estampa apocalíptica de los tiempos de la guerra cristera: El triunfo de Cristo Rey de Gonzalo Carrasco Espinosa SJ
}

$\mathrm{P}$ ARA LA MAYORÍA DE LOS ESTUdiosos de la historia del arte mexicano de finales del siglo xIx y principios del siglo xx, Gonzalo Carrasco Espinosa SJ (Otumba I859-Puebla I936) fue un pintor decimonónico que vivió una larga vida. Pocos lo consideran un pintor del siglo xx, aunque alcanzó a ser contemporáneo de la Escuela Mexicana de Pintura y su trabajo de madurez fue realizado al tiempo en que se desarrolló el movimiento muralista en México.

Justino Fernández hace una breve mención de su trabajo como destacado estudiante de la Escuela Nacional de Bellas Artes entre i877 y i884, fecha en la que ingresó a la Compañía de Jesús. La crítica de arte de mediados del siglo xx no le fue favorable, ya que su elección como artista consistió en una terca fidelidad a los modelos aprendidos de sus maestros José Salomé Pina y Rafael Flores, y sus temáticas se orientaron prioritariamente a lo sacro, en un afán de apoyar a una prédica visual en los agitados tiempos de la revolución mexicana.

Aunque su trabajo ha sido recientemente estudiado más a fondo en un catálogo, ${ }^{\mathrm{I}}$ una publicación ${ }^{2}$ y mi tesis doctoral, ${ }^{3}$ el análisis de su pintura, realizado

I. Fausto Ramírez, "Gonzalo Carrasco (I859-1936), Job en el estercolero, I88I”, en Esther Acevedo et al., Catálogo comentado del acervo del Museo Nacional de Arte. Pintura. Siglo XIX, México, Museo Nacional de Arte/Consejo Nacional para la Cultura y las Artes/Universidad Autónoma de México-Instituto de Investigaciones Estéticas, 2002, t. I, p. I07.

2. Margarita Hanhausen et al., La pintura y la palabra. Dos artistas jesuitas mexicanos: Gonzalo Carrasco y Miguel Aguayo, México, Universidad Iberoamericana, 2005.

3. Margarita Hanhausen, "Gonzalo Carrasco: jesuita y artista mexicano", tesis presentada para 
durante la segunda mitad del siglo xx, ha sido en general escaso. Fernández lo menciona en la primera edición de su libro de 1952: Arte moderno y contemporáneo de México. ${ }^{4}$ Existe una crítica más amplia, aunque superficial y subjetiva hecha por el jesuita Wilfredo Guinea SJ, incluida en la biografía que Xavier Gómez Robledo SJ publicara en 1959..$^{5}$ Montserrat Galli escribió un breve ensayo sobre los años de estudiante de Carrasco en la Escuela Nacional de Bellas Artes, que se incluyó en la introducción al catálogo de la exposición que, en 1996, la familia Carrasco organizara en la ciudad de Puebla. ${ }^{6}$

\section{Elpintor jesuita}

Carrasco profesó en la Compañía de Jesús en i884, momento en que dejó la historia del arte mexicano. Sin embargo, los 52 años que mediaron entre su ingreso a la Compañía de Jesús y su muerte, en enero de 1936, fueron muy fructíferos en la producción de un arte religioso que, por negarse a abandonar el canon académico, se fue transformando en una manifestación plástica anticuada, aunque muy del gusto de los sectores conservadores. Fue, asimismo, autor de numerosos retratos realistas, siguiendo el estilo del pintor español Federico Madrazo, activo en la corte de Madrid a finales del siglo XIX.

Para Justino Fernández el periodo final de la vida de Carrasco queda resumido en pocos renglones: "En I884 abandonó la pintura para hacer estudios y ordenarse sacerdote y más adelante volvió a producir una serie de pinturas de inferior calidad respecto de la primeras y aún hizo decoraciones murales en el templo de la Sagrada Familia y en otras iglesias de la República". 7

Sin embargo, su obra plástica como jesuita representó material suficiente para ser un tema de investigación doctoral y ampliar un poco más esta opinión. El que

optar por el grado de doctora en Historia del Arte, México, Universidad Autónoma de MéxicoFacultad de Filosofía y Letras, 2006.

4. Justino Fernández, El arte del siglo XIX en México, México, Universidad Autónoma de México-Instituto de Investigaciones Estéticas, 1983, primera parte de la edición por separado del Arte Moderno y Contemporáneo de México.

5. Xavier Gómez Robledo SJ, Gonzalo Carrasco, el pintor apóstol, México, Buena Prensa, 1959.

6. Montserrat Galli Boadella et al., Gonzalo Carrasco. La pintura del espiritu, Puebla, Universidad Iberoamericana/Universidad Popular Autónoma del Estado de Puebla/Secretaría de Cultura del Gobierno del Estado de Puebla, 1996 (catálogo de la exposición).

7. Fernández, op. cit., p. 139. 
Carrasco fuera el artista favorito de los católicos conservadores, grupo marginado por el discurso artístico de la revolución, no debiera ser razón para considerar su trabajo falto de interés académico. La obra mural de la Sagrada Familia, realizada entre 1922 y 1924, contemporánea a la decoración de los muros de San Ildefonso por los jóvenes artistas contratados por Vasconcelos, siguió modelos de la segunda mitad del siglo XIX y, aún así, constituye una obra relevante para dar a Carrasco un lugar en la historia del arte mexicano contemporáneo.

El discurso plástico del programa iconográfico de dicho templo se antoja demasiado cargado de ideología. Esto no sería obstáculo para que por lo menos fuese considerado un discurso interesante, tomando en cuenta que fue ejecutado con maestría técnica, que logró la comunicación con su público y constituyó un ejemplo sobresaliente de un templo católico decorado en las primeras décadas del siglo Xx. En esta empresa Carrasco recibió el apoyo de un jesuita mexicano con disposición y cierta habilidad artística: Manuel Tapia SJ, apodado "El Grandote".

La personalidad artística de Carrasco no se puede separar de su personalidad como religioso. Puso su talento como pintor al servicio de su ministerio y esto le confirió algunas características a su trabajo y también fue causa de cierto estancamiento. Muchas de sus obras se repiten y era raro que se detuviera a bosquejar primero una obra. En su taller tenía siempre entre siete y io pinturas de distintos tamaños e importancia que procedía a completar por etapas. ${ }^{8} \mathrm{El}$ que la técnica empleada fuese el óleo sobre lienzo le facilitaba este ritmo de trabajo: mientras unas obras se secaban, él podía ir detallando otras e inclusive empezar el "manchado" de los nuevos encargos — usando la palabra que él utilizaba para describir su manera de abocetar.

Sus bocetos al óleo constituyen ejemplos de gran interés artístico para el estudioso de su pintura. Los "manchados" aúnan la correcta labor de dibujo, composición y disposición de los volúmenes y perspectivas, con una refrescante espontaneidad, además de permitir la experimentación con los colores más vivos de su paleta, muchos de ellos aplicados sin mediar mezcla alguna, tomados directamente del tubo de pigmento. Dada la forma como se vio obligado a organizarse, con el fin de compaginar eficazmente su trabajo pastoral con el artístico, no solía hacer bocetos preparatorios, desarrollando una forma de detallar el cua-

8. Esto se saca en conclusión al leer varias entradas de su Diario de I9IO-I9I2, conservado en el Archivo Histórico de la Provincia Mexicana de la Compañía de Jesús en la ciudad de México (АнРмсј). 
dro a partir del manchado. En el tiempo en el que realicé la investigación para optar por el grado de doctorado, tuve conocimiento de tan sólo cinco de estos admirables bocetos, la mayoría en pequeño formato, que permiten apreciar otra faceta de sus dotes como artista, al no estar atado por las exigencias académicas de terminar una obra con todo detalle.

En I895, durante la ceremonia de coronación de la Guadalupana, realizó, desde el coro de la basílica, el apunte al óleo con el título de La coronación de la célebre imagen. El trabajo recibió una crítica muy favorable, dada la celeridad de su ejecución y la exactitud para reproducir la escena que se desarrollaba en el templo. ${ }^{9}$ Esto sólo fue posible dada la habilidad y el oficio adquiridos como alumno de la Escuela Nacional de Bellas Artes, a la que ingresó en los cursos regulares en $\mathrm{I} 876 .^{\mathrm{IO}}$

\section{Una visión apocalíptica de la guerra cristera}

El boceto, tema de este estudio y propiedad de la Compañía de Jesús, titulado El triunfo de Cristo Rey, ${ }^{\text {II }}$ se conserva en la residencia jesuita de la calle de Enrico Martínez, en la ciudad de México. Al carecer de fecha o firma es, en estricto sentido, una atribución pero que, tomando en cuenta que en técnica y temática recuerda otras obras de Carrasco, a manera de una especie de "suma" de varios motivos empleados por él anteriormente en pinturas firmadas, no constituye una hipótesis arriesgada. Los jesuitas que vivieron en esa residencia, contemporáneos a Carrasco, transmitieron a los que fueron llegando que esa obra había sido pintada por él. Esta tradición se ha sostenido a lo largo de los setenta años transcurridos desde la muerte del pintor.

9. Este boceto al óleo fue parte de la exposición Los Pinceles de la Historia III presentada en el Museo Nacional de Arte de la ciudad de México en 2003. Cfr. Jaime Cuadriello, "La Corona de la Iglesia para la reina de la Nación”, en Los pinceles de la Historia III. La fabricación del Estado, I864I9I0, México, Museo Nacional de Arte/Consejo Nacional para la Cultura y las Artes/Universidad Autónoma de México-Instituto de Investigaciones Estéticas, 2003, pp. I50-I85.

Io. Fue un excelente alumno que llegó a ganar varios premios en las exposiciones de la escuela, que le valieron el que sus obras maestras de este periodo: Job en el estercolero realizada en I88 y $\mathrm{La}$ caridad de san Luis Gonzaga en la peste de Roma, en 1893, fuesen incluidas en los catálogos de dos exposiciones internacionales en las que participó México.

II. En agosto de 2004 fui invitada por el entonces director de la Obra Nacional de la Buena Prensa a dar mi opinión sobre la posibilidad de que ese boceto fuera una obra de Gonzalo Carrasco. 
Se trata de un pequeño óleo sobre bastidor de apenas $48 \times 59 \mathrm{~cm}$, precariamente conservado, ya que en 2004 aparecía cubierto con una gruesa capa de polvo y deyecciones de mosca, con un rasguño considerable en la parte superior derecha, en la zona de cielo bajo y el grupo de ángeles. Los colores son vivos y atraen fuertemente la atención sobre el "rompimiento de Gloria" en tonos de anaranjado, amarillo y rosado, cuyo centro enmarca la menuda figurita de Cristo Rey, nimbada con una corona de rayos de luz, pintados con veladuras blancas.

El tema corresponde a un episodio contemporáneo de la historia del conflicto cristero, desarrollado en México entre 1926 y 1930. Carrasco mezcla en esta pintura citas de historia contemporánea, tomadas del fotoperiodismo de la época, con figuras religiosas que evidencian el patrocinio trascendente de Cristo y la Guadalupana para con el pueblo católico de México. En cuanto a la composición, la pintura aparece dividida en dos planos claramente señalados, donde dos tercios celestes son el escenario de la Guadalupana suplicante, rodeada de la corte angélica de la Salve Reina de América Latina (I9IO), conservada en el Museo de la Basílica de Guadalupe, de la lucha de san Miguel contra los demonios, de la exaltación de la Santa Cruz portada por ángeles, rodeando a Cristo en majestad, como emperador del universo.

Bajo estos registros celestes, en el tercio horizontal inferior, se aprecia, de izquierda a derecha, el sufrimiento paciente de los católicos perseguidos: los ahorcados, el fusilamiento del jesuita Miguel Agustín Pro SJ, las víctimas de toda contienda armada y la ruina demolida del basamento de la imagen de Cristo Rey, colocada originalmente en la cima del cerro del Cubilete.

Del lado derecho, entra a escena el ejército del general Enrique Gorostieta, portando una bandera blanca mientras que, sobre las palmas del martirio, Carrasco coloca los cuerpos yacentes de cinco sacerdotes que combatieron en las filas del ejército cristero. En un segundo plano, del lado derecho, se muestra la fachada de la Basílica de Guadalupe, donde una muchedumbre, realizada con menudas pinceladas de color, se arremolina ante sus puertas cerradas. En el horizonte, al fondo, se aprecian los volcanes que rematan por el oriente el valle de México y la silueta, nimbada por un arco iris, de la Basílica de San Pedro en Roma.

El triunfo de Cristo Rey (fig. I) debió de ser realizada en algún momento de la segunda mitad de 1929. Ayudan a fijar esta fecha aproximada la representación de los episodios que aparecen en la franja inferior: la escena del fusilamiento del padre Pro, que tuvo lugar en noviembre de 1928; la voladura del monumento del Cubilete en enero de 1929; la muerte en combate del padre Reyes Vega, en marzo de 1929, así como el que las puertas de la Basílica de Guadalupe permane- 


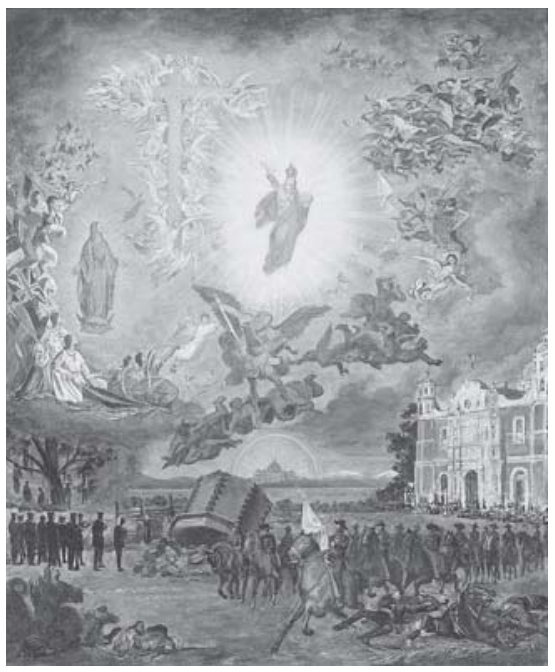

I. Gonzalo Carrasco, El triunfo de Cristo Rey, óleo sobre tela, sin fecha o firma, tomada de Margarita Hanhausen et al., La pintura y la palabra. Dos artistas jesuitas mexicanos: Gonzalo Carrasco y Miguel Aguayo, México, Universidad Iberoamericana/Fundación Bustos Barrena SJ, 2005, p. 25. Actualmente la imagen se encuentra en la residencia jesuita de la calle de Enrico Martínez núm. 9, centro histórico, ciudad de México. Reproducción autorizada por la Provincia Mexicana de la Compañía de Jesús.

cieran cerradas, indicando que aún no se habían llevado a cabo las pláticas entre el gobierno y la Iglesia católica mexicana que en 1930 permitirían la reapertura de los templos.

A la fecha no se conocen más datos que refieran los motivos para realizar el boceto o su posible destino. ¿Acaso fue un encargo? ¿Una iniciativa personal a manera de reflexión sobre los sucesos que el México católico vivía? ¿Una meditación ignaciana con el tema de "las dos banderas", ${ }^{12}$ desplegando la batalla en el escenario histórico del México de entonces? Cuesta trabajo pensar que ese boceto se transformaría en breve en un lienzo de proporciones épicas, cuando Carrasco era ya un hombre de setenta años y el conflicto entre la Iglesia y el Estado seguía sin resolverse.

Mientras que su paleta cuando estudiante era más bien sombría, semejante a la del Siglo de Oro español, el colorido característico en las pinturas de Carrasco de las últimas dos décadas de su vida se fue haciendo cada vez más vivo. Una razón podría ser la facilidad del uso de colores producidos industrialmente, tal

I2. La "Meditación de las dos banderas" aparece en el libro de los Ejercicios espirituales de Ignacio de Loyola. El tema hace referencia al enfrentamiento entre Cristo y Satán con una escenografía de batalla renacentista, donde se invita al ejercitante a tomar partido entre esas dos fuerzas. Véase san Ignacio de Loyola, Exercicios espirituales, autógrafo español, II $^{\mathrm{a}}$ ed., Madrid, Apostolado de la Prensa, 1979, pp. 79-82. 
vez también alguna influencia involuntaria de la pintura moderna de entonces. El padre José Gutiérrez Casillas SJ, la única persona viva que conoció a Carrasco en persona y que me fue posible entrevistar, achacaba la brillantez de su paleta a "un defecto visual" del cual no he tenido más confirmación documental. Dicho jesuita conoció a Carrasco alrededor de 1932, cuando él era un niño de aproximadamente unos doce años de edad, por lo que bien pudo ser una apreciación personal totalmente subjetiva. ${ }^{13}$ Lo que sí es factible es que hubiera cierto influjo inconsciente en su paleta de la Escuela Mexicana de Pintura, la cual estaba empleando colores muy vivos, con el fin de identificarse con una de las facetas visuales más reconocibles de la artesanía mexicana, así como con el colorido de la ilustración gráfica y las artes aplicadas en la década de los años veinte y treinta.

Es característico el tono de rosa-anaranjado empleado en el "rompimiento de Gloria”, frecuente en sus composiciones de las décadas de los años veinte y treinta. Los cielos que pinta son los del Altiplano: atmósferas transparentes con una peculiar gama de colores dada por la altura. Siempre que representa las figuras de santos en la Gloria las muestra entronizadas, en nubes iluminadas por el amanecer, mientras que en el fondo de la escena brilla el sol poniente de estas latitudes, mezclando así en la atmósfera dos tiempos físicos: una forma plástica de representar la eternidad, más allá del tiempo natural. Un ejemplo a tomar como referencia es el mural del ábside de la Sagrada Familia, donde la rodea con colores semejantes.

\section{El pintor jesuita en tiempos de la revolución mexicana}

Carrasco había vivido el anticlericalismo revolucionario y la persecución en contra de la Iglesia Católica, cuando rector del Colegio de Tepotzotlán en 19I4, uno más de los importantes cargos que desempeñaría en su larga carrera como jesuita. En ese tiempo pasó de ser prisionero del ejército carrancista a convertirse en amigo personal del jefe constitucionalista, de quien se dice hizo un retrato que nunca llegó a manos del general Venustiano Carranza. El ofrecimiento de uno de los generales carrancistas de llevarlo a México y nombrarlo director de la Escuela Nacional de Bellas Artes, con la condición de la apostasía y el abandono

I3. Margarita Hanhausen, entrevista al padre José Gutiérrez Casillas SJ, Biblioteca Mariano Cuevas, Instituto Teológico de la Compañía de Jesús, Churubusco, ciudad de México, 29 de septiembre de 2000 . 
del sacerdocio, pareció motivar que las autoridades jesuitas y los altos sectores eclesiásticos buscaran enviarlo cuanto antes fuera de México. Carrasco había dejado claro en una carta al general Coss que iba a ser más sencillo matarlo que hacer que un soldado viejo abandonara su bandera, aunque se ponía a sus órdenes como sacerdote católico y como pintor. Cuando salió en I9I4 rumbo a Nueva York, su pasaporte asentaba esas dos profesiones. No volvería a México sino hasta entrado I9I8.

Se considera que el motivo real para enviarlo a Estados Unidos era que se necesitaba que se abocase a la producción de pinturas comercializables y que el producto de su venta fuese destinado a sostener los gastos de los noviciados jesuitas en el exilio. Carrasco pudo así, por órdenes expresas de sus superiores, dedicarse a desarrollar su labor como pintor de tiempo completo y, en sus propias palabras, los años en Nueva York fueron los únicos de su vida después de su época de estudiante en que se dedicó por completo a esta actividad. Presentó una exposición y atendió multitud de encargos de retratos e imágenes religiosas para los templos católicos de la zona y recabó una considerable suma para apoyar a los noviciados jesuitas en el "exilio".

No dejó de realizar una actividad pastoral paralela, tanto con los mexicanos residentes como con los que llegaban a Nueva York haciendo escala rumbo a Europa, donde buscaban refugio debido al recrudecimiento de la Revolución. Fue en ese tiempo cuando conoció al joven Miguel Agustín Pro SJ, quien pasó por Nueva York rumbo a España con algunos compañeros.

No volvería a saber de él hasta que le llegó la noticia, estando en Puebla, de que aquel jesuita de 36 años había sido implicado en un complot para asesinar al general Obregón y que había sido fusilado junto con otros miembros de la Asociación Católica de Jóvenes Mexicanos (ACJM), que se habían mostrado agresivamente contrarios a la política anticatólica del gobierno del general Calles (figs. 2 y 3). Carrasco pintó el retrato del padre Pro, conservado desde entonces en la capilla doméstica de la residencia de Enrico Martínez, en el que representaba el busto de este joven jesuita con la reverencia debida a un mártir, mucho antes de que el Vaticano lo beatificara.

Si bien la comunidad de Tepotzotlán no había sufrido, en I9I4, más que el encarcelamiento injusto y el maltrato de palabra, el rostro intolerante de la Revolución fue inmediatamente reconocido por Carrasco conforme avanzaba la década de los años veinte. Cuando en ig25 la Sagrada Familia fue cerrada, bajo pretexto de que, al ser una iglesia construida después de 1917, no contaba con los permisos de Gobernación, un motín popular de las feligresas de 


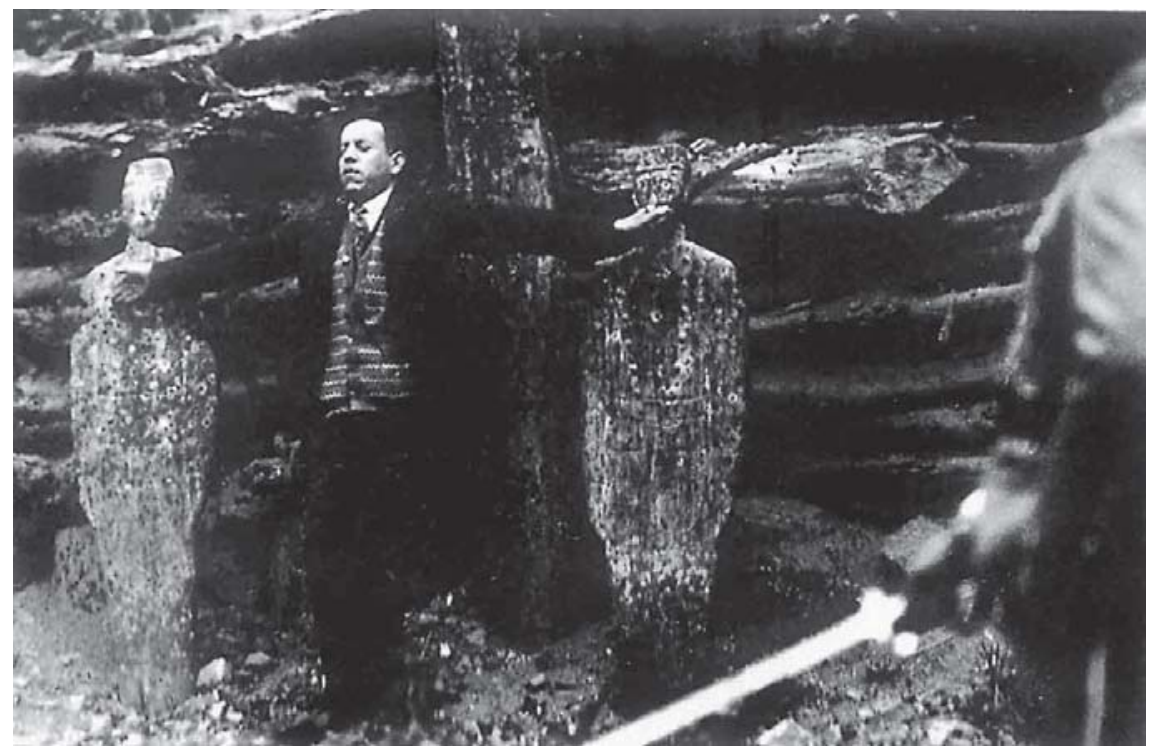

2. Fusilamiento del padre Miguel Agustín Pro SJ. Fotografía tomada de Renato González Mello et al., Los pinceles de la Historia IV: La arqueología del régimen I9I0-I955, México, Museo Nacional de Arte/Consejo Nacional para la Cultura y las Artes/Universidad Nacional Autónoma de México-Instituto de Investigaciones Estéticas, 2003, p. Io9. Colección Condumex.

la zona obligó a abrirla de nuevo al culto, pero el provincial de los jesuitas decidió que Carrasco fuera enviado a Puebla en 1926. La obra plástica de los últimos Io años de su vida presentaría una fortísima carga ideológica.

En El triunfo de Cristo Rey, Carrasco incorpora las escenas de la parte inferior a manera de la composición multiepisódica de las primeras planas de los periódicos de entonces, donde varias fotografías eran agrupadas con el fin de proporcionar al lector una visión panorámica del tema que luego tratarían en los artículos y editoriales.

Carrasco presenta las escenas no exentas de teatralidad, unificándolas en una sola línea temporal, como sucedidas en el mismo tiempo y espacio, en distintos planos del mismo escenario. La escena del fusilamiento del padre Pro, enfrentando al pelotón con los brazos abiertos en cruz, fue tomada de las fotografías que el periódico Excélsior publicó a ocho columnas io días después del fallido atentado del I3 de noviembre de 1927, cuando los hermanos Miguel Agustín 


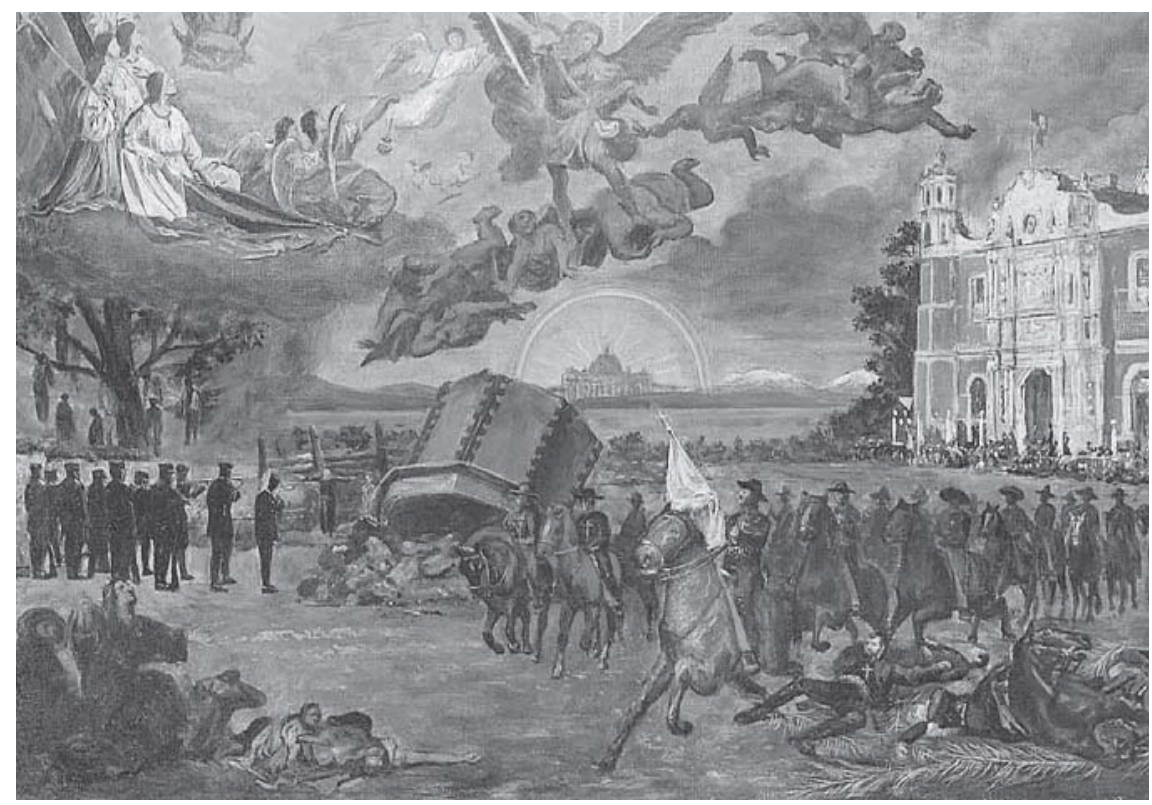

3. Gonzalo Carrasco, El triunfo de Cristo Rey, óleo sobre tela, sin fecha o firma. Detalle de la esquina inferior izquierda mostrando el fusilamiento del padre Pro, tomado de Margarita Hanhausen et al., La pintura y la palabra. Dos artistas jesuitas mexicanos: Gonzalo Carrasco y Miguel Aguayo, México, Universidad Iberoamericana/Fundación Bustos Barrena SJ, 2005, p. 25.

y Humberto Pro, el ingeniero Luis Segura Vilchis y Juan Tirado Arias fueron fusilados, tras un juicio sumario, acusados de conspirar contra el presidente.

Un estudio detallado de la serie de fotografías de esa ejecución muestra cómo Carrasco hace un montaje compositivo basado en dos momentos sucesivos de las ejecuciones del padre Miguel Agustín Pro SJ y del ingeniero Segura, ya que el fusilado abre los brazos en cruz como el primero y la posición del pelotón de fusilamiento es exacta a la registrada en la foto del segundo. ${ }^{\text {I4 }}$ Junto a esta escena, a la izquierda, destaca un árbol con ahorcados, tomada quizá de una de las múltiples postales que circularon en esos tiempos del conflicto cristero.

I4. Nasheli Jiménez del Val, "El martirio del Padre Pro”, en Renato González Mello et al., Los pinceles de la Historia IV: La arqueología del régimen I9I0-1955, México, Museo Nacional de Artel Consejo Nacional para la Cultura y las Artes/Universidad Nacional Autónoma de México-Instituto de Investigaciones Estéticas, 2003, pp. I07-II4. 

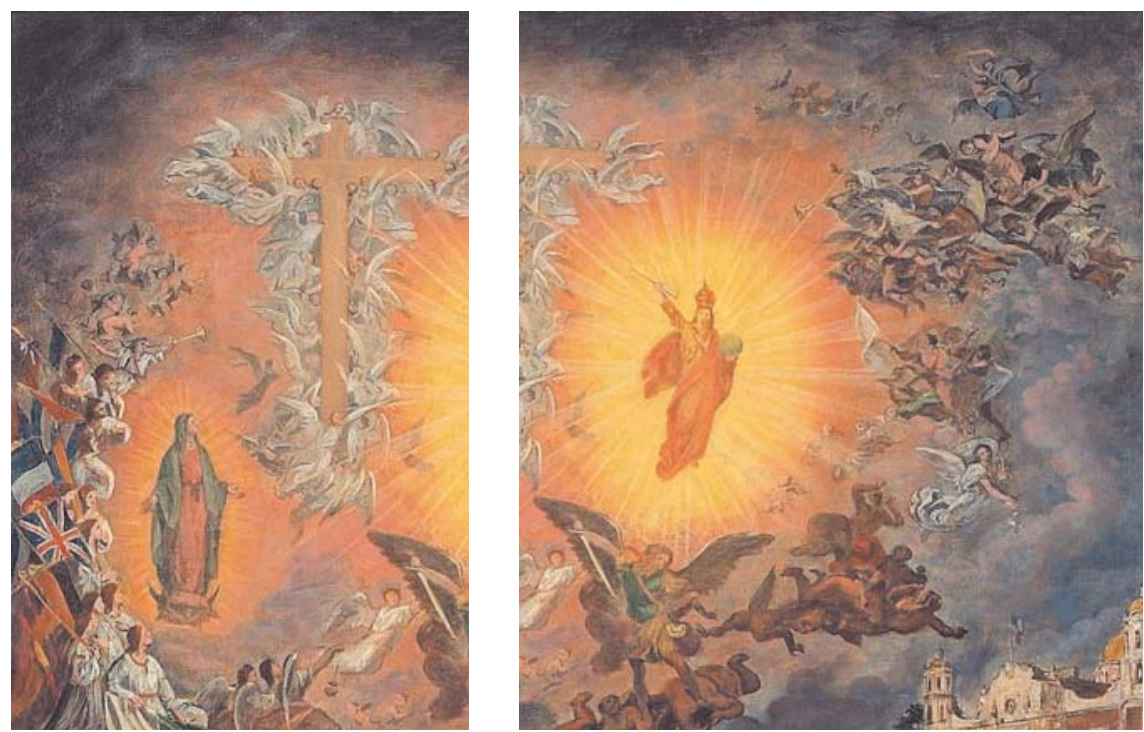

4 y 5. Gonzalo Carrasco, El triunfo de Cristo Rey, óleo sobre tela, sin fecha o firma. Tercio vertical izquierdo y dos tercios verticales derechos, tomados de Margarita Hanhausen et al., La pintura y la palabra. Dos artistas jesuitas mexicanos: Gonzalo Carrasco y Miguel Aguayo, México, Universidad Iberoamericana/Fundación Bustos Barrena SJ, 2005, p. 25.

La composición presenta dos tercios horizontales de cielo, ocupados por una representación de la Iglesia triunfante y por un tercio terrestre, escenario del devenir de la Iglesia militante. Esta lectura se enriquece con la división vertical de un tercio de colores más sombríos del lado izquierdo por dos tercios luminosos en el centro y la derecha (figs. 4 y 5 ). Al centro de la pintura, a manera de división, la imagen de la ruina del primer monumento a Cristo Rey en el cerro del Cubilete, Guanajuato, demolido por órdenes del general Amaro en enero de 1928, durante la etapa más severa del conflicto.

Si se recuerda el recurso ignaciano de meditación de la "composición viendo el lugar", propuesta en los Ejercicios Espirituales de Loyola, se podrán identificar en la obra, tema del presente ensayo, elementos propios de la meditación de "las dos banderas", traspolados a una escena contemporánea. Se trata de utilizar la imaginación activa y de construir mentalmente una escena, 
donde el ejército de las tinieblas, desde su "cátedra de fuego y humo" combate con el ejército de la luz. ${ }^{15}$

Conociendo el estilo de Carrasco para componer sus alocuciones, conservadas la mayoría en notas sueltas entre sus papeles resguardados en el Archivo Histórico de la Provincia Mexicana de la Compañía de Jesús, la composición de este boceto da la impresión visual de la toma de notas para una prédica en la que la historia contemporánea de México es presentada con tintes apocalípticos.

Un texto suyo de 1925 — año en que el presidente Calles apoyó abiertamente el desarrollo de la Iglesia Católica Apostólica Mexicana y se produjo el cisma religioso de Tabasco en tiempos del gobierno de Tomás Garrido Canabal—, ${ }^{16}$ citado por Gómez Robledo, ofrece luz sobre la posible inspiración de algunos elementos de esta pintura, expresados con tintes apocalípticos:

\begin{abstract}
Ahora, Señor, me parece entrar en un nuevo mundo, lleno de luz, de fatigas gloriosas con horizontes vastísimos, en medio de este nuevo paganismo, en esta persecución actual que se presenta feroz como una tempestad no vista antes, con este radicalismo y brutalidad espantosa de asesinatos injustificados, robos de templos no vistos jamás, trastornos de leyes, de principios fundamentales, como el respeto a la propiedad, al derecho a Tu Ley Santa; corrupción espantosa que prende y se propaga como un incendio aun en gente piadosa; persecución abierta al clero pidiendo que se casen los sacerdotes, que sean esclavos del gobierno, etc. Todo este conjunto pide virtudes nuevas, celo más robusto, oración más ardiente y frecuente; es decir, la imitación de los primeros apóstoles. ${ }^{17}$
\end{abstract}

I5. De Loyola, op. cit., pp. 6I-63: "Ver a Christo [sic] nuestro Señor, rey eterno, y delante de él todo el universo mundo, al qual [sic] y cada uno en particular llama y dice: Mi voluntad es de conquistar todo el mundo y todos los enemigos, y así entrar en la gloria de mi Padre, por tanto quién quisiere venir conmigo, ha de trabajar conmigo, porque siguiéndome en la pena, también me siga en la gloria", y pp. 79-80: "La segunda composición viendo el lugar será aquí ver un gran campo [...] adonde el sumo capitán de los buenos es Christo nuestro Señor y otro campo [...] donde el caudillo de los enemigos es Lucifer [...] Imaginar así como si se asentase el caudillo de todos los enemigos en aquel gran campo de Babilonia, como en una grande cátedra de fuego y humo, en figura horrible y espantosa".

16. Cfr. Carlos Martínez Assad, "Un modelo religioso diferente”, en Breve historia de Tabasco, cap. V, sección 6, publicación digital: http://biblioteca.redescolar.ilce.edu.mx/sites/estados/libros/tabasco/html/tabasco.html

I7. Gómez Robledo, op. cit., p. 264. 
6. Gonzalo Carrasco, El triunfo de Cristo Rey, óleo sobre tela, sin fecha o firma. Detalle, figura de Cristo Rey, tomado de Margarita Hanhausen et al., La pintura y la palabra. Dos artistas jesuitas mexicanos: Gonzalo Carrasco y Miguel Aguayo, México, Universidad Iberoamericana/Fundación Bustos Barrena SJ, 2005, p. 25.

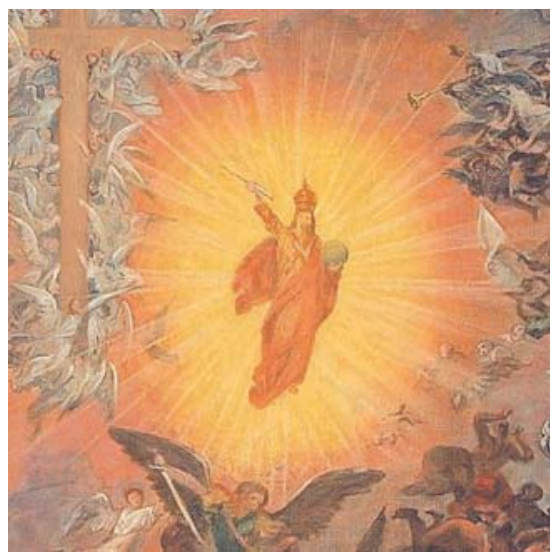

La descripción del clima de caos y desorden terrenal es similar al representado en el boceto, con terribles muestras de violencia. Sin embargo, en El triunfo de Cristo Rey, Carrasco busca lograr una especie de catarsis al presentar la acción de los planos trascendentes, velando sobre el devenir de la historia de un México que, desde la perspectiva de un sacerdote católico, no tiene más horizonte y futuro que el terminar acogido a las directrices de Roma.

\section{Las fuentes de inspiración}

Es posible que Carrasco encontrara elementos indirectos de inspiración en las militantes estrofas del himno guadalupano y del himno de Cristo Rey, del dominio público, presentando las certezas del patrocinio guadalupano y del inminente reinado terreno de Jesús sobre México, a manera de glosa popular del Salmo $19 .{ }^{18}$

El personaje principal de este boceto es Cristo Rey, representado en una suerte de visión apocalíptica: en medio de una corona radiante, una figurita de escasos centímetros impera sobre la composición desde el centro del rompimiento de gloria. ${ }^{19} \mathrm{El}$ potente resplandor que de ella emana constituye el punto de atracción visual del cuadro, unificando en torno a sí todas las demás escenas (fig. 6).

I8. Del Salmo I9: "Ahora reconozco que el Señor da la victoria a su ungido, que lo ha escuchado desde su santo cielo, con los prodigios de su mano victoriosa”. Compárese con la estrofa del himno a Cristo Rey: "Tú reinarás porque dijiste 'Reinaré”".

I9. Apoc. I, I6: "Su rostro era como el Sol cuando resplandece en su fuerza". 


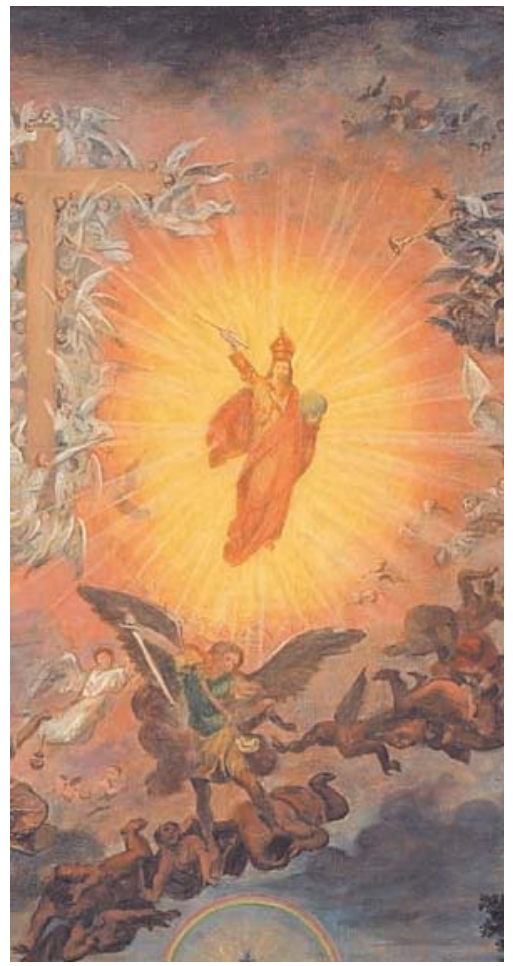

7. Gonzalo Carrasco, El triunfo de Cristo Rey, óleo sobre tela, sin fecha o firma. Detalle, Cristo Rey y san Miguel arcángel, tomado de Margarita Hanhausen et al., La pintura y la palabra. Dos artistas jesuitas mexicanos: Gonzalo Carrasco y Miguel Aguayo, México, Universidad Iberoamericana/ Fundación Bustos Barrena SJ, 2005, p. 25.

Para componer tal figura, Carrasco junta varios elementos iconográficos propios del Cristo resucitado y en majestad, tocado con la triple tiara, ${ }^{20} \mathrm{em}-$ puñando el cetro y sosteniendo el orbe. Para indicar visualmente que Cristo Rey está fuera del tiempo, lo representa como una viviente suma de su historia personal y de la historia de la salvación. Es, a un tiempo, el anciano apocalíptico y el joven nazareno barbado, coronado y vestido de rojo, simbolizando el amor heroico hasta el martirio. Carrasco hace surgir a Cristo de la ruina del pedestal demolido en el cerro del Cubilete, como si emergiera del sepulcro, subrayando su carácter triunfante.

En la sección mostrada en la figura 7 se aprecia el discurso visual de la figura de Cristo Rey, bajo él, el arcángel san Miguel en plena lucha y sobrevolando la mole distante de la silueta de la sede vaticana: la Basílica de San Pedro en Roma.

20. En latín, el triregnum, símbolo del Pontificado Católico Romano. 

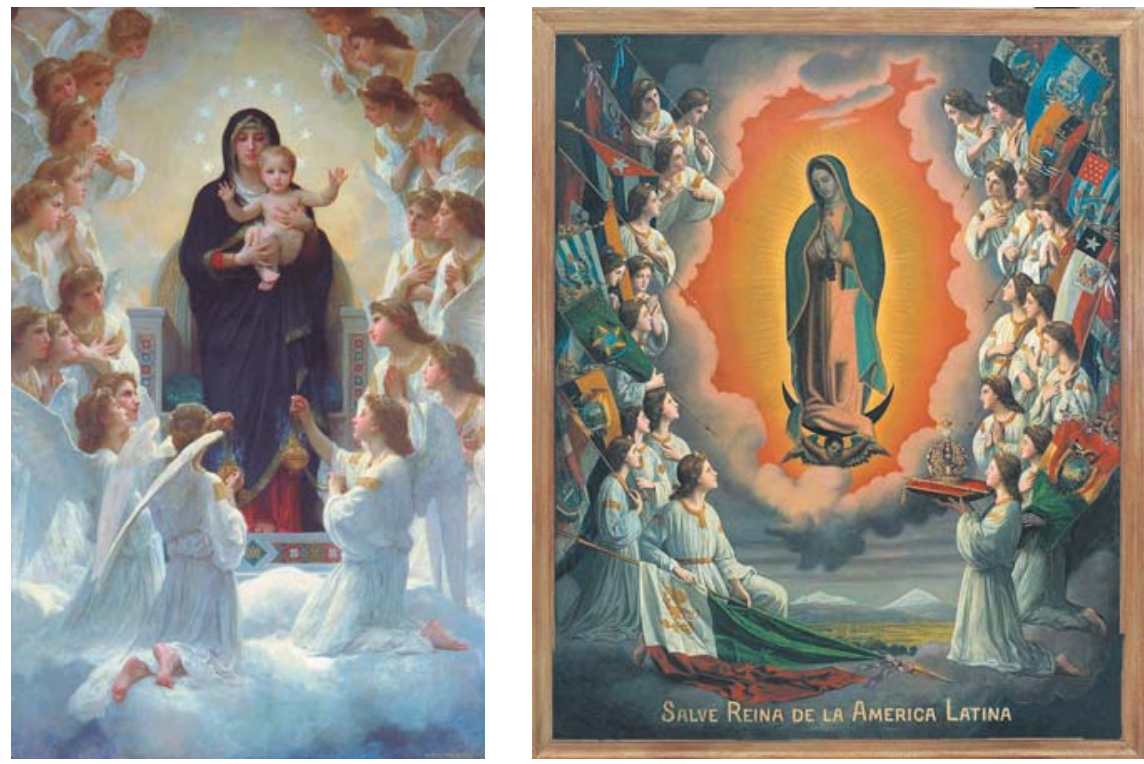

8 y 9. William Adolphe Bouguereau, Regina Angelorum, I900, óleo sobre tela.

Col. Museo de Orsay; Gonzalo Carrasco Salve Reina de América Latina, I910, óleo sobre tela, tomada de Los pinceles de la Historia III. La fabricación del Estado, I864-I9Io, México,

Museo Nacional de Arte/Consejo Nacional para la Cultura y las Artes/Universidad Nacional Autónoma de México-Instituto de Investigaciones Estéticas, 2003, p. I80.

Col. Museo de la Basílica de Guadalupe.

No podía faltar en este cuadro la Virgen de Guadalupe. Durante su vida Carrasco pintó reiteradas veces esta imagen, fuese de manera tradicional o imprimiéndole modificaciones compositivas, como fue el caso de la Salve Reina de América Latina, para la cual adaptó la corte angélica de Regina Angelorum de William Adolphe Bouguereau (figs. 8 y 9).

Todavía no es la Guadalupana apocalíptica que, tomándose muchas libertades iconográficas, representaría en dos lienzos pintados en 1932 y conservados en la residencia jesuita de la ciudad de Puebla. En ellos la Virgen María, abandonando el recogimiento con el que muestra la iconografía tradicional, y que Carrasco reprodujo en varias ocasiones desde finales del siglo XIX, se transforma en una imagen activa y combatiente, sea como protectora de la niñez mexicana, indefensa ante las acechanzas de la Bestia de Siete Cabezas, o como la enemiga de esta figura monstruosa, a la que ataca plácidamente con una lanza en forma 


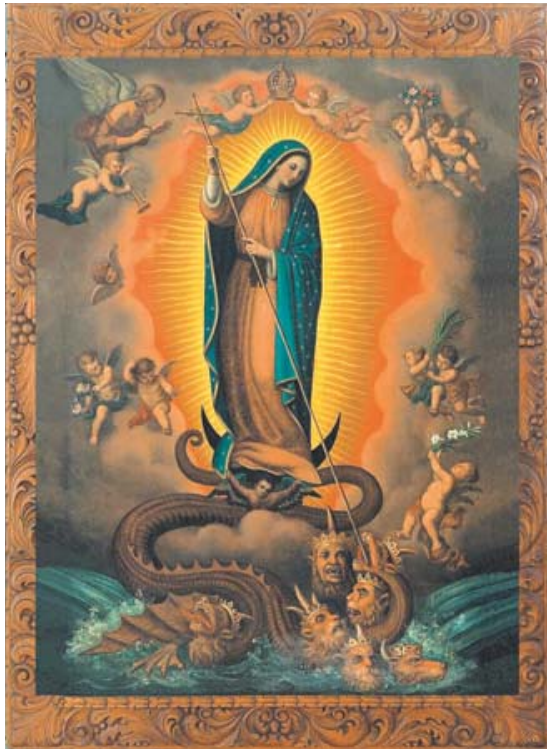

Io. Gonzalo Carrasco, La Virgen de Guadalupe venciendo a la bestia apocalíptica, s/f, óleo sobre tela, I50 × IOI cm, tomada de Margarita Hanhausen et al., La pintura y la palabra. Dos artistas jesuitas mexicanos: Gonzalo Carrasco y Miguel Aguayo, México, Universidad Iberoamericana/Fundación Bustos Barrena SJ, 2005, p. 68. Este cuadro se encuentra actualmente en la residencia jesuita de Puebla.

de cruz (fig. Io). Es significativo que dos de las cabezas de la bestia recuerdan los rasgos de los presidentes Obregón y Calles. ${ }^{2 \mathrm{I}}$

La Guadalupana de El triunfo de Cristo Rey aparece vestida convencionalmente con túnica rosa y manto azul, rodeada por una corte angélica, como cita de otro lienzo de Carrasco, pintado a principios del siglo y conservado en la Basílica de Guadalupe: Salve Reina de América Latina, inspirado en la Regina Angelorum (1900) de Bouguereau (I825-1905). El coro de ángeles custodios de las naciones, portando banderas, no le ofrece esta vez la corona imperial sino que la imita en el gesto de volverse suplicante hacia su Hijo (fig. II). En estos años, antes de la evolución del concepto mariológico auspiciado por el Concilio Vaticano II, se invocaba a la Virgen María como a la "omnipotencia suplicante", subrayando así su carácter de suprema intercesora.

Como en el episodio evangélico de las bodas de Canaan, ${ }^{22}$ ella se vuelve a su Hijo, mostrando la miseria de sus devotos y la necesidad de que sea Él quien les dispense el socorro. El "mira que no tienen vino...", aquella anécdota evangéli-

2I. Gómez Robledo, op. cit., p. 293.

22. Jn. 2, 3-5. 
II. Gonzalo Carrasco, El triunfo de Cristo Rey, óleo sobre tela, sin fecha o firma.

Detalle de El triunfo de Cristo Rey: Guadalupana suplicante, tomado de Margarita Hanhausen et al., La pintura y la palabra. Dos artistas jesuitas mexicanos: Gonzalo Carrasco y Miguel Aguayo, México, Universidad Iberoamericana/Fundación Bustos Barrena SJ, 2005, p. 25.

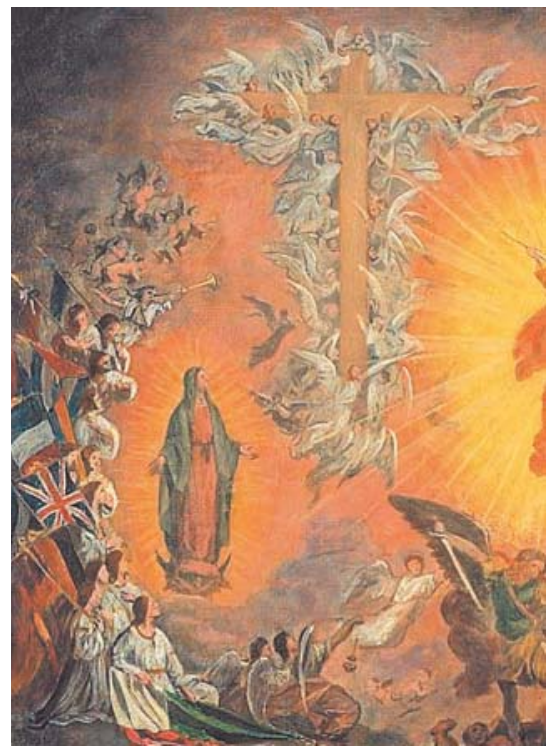

ca, se transforma en El triunfo de Cristo Rey en una urgente súplica por el México católico: sus ojos y los del coro de ángeles que la rodea están fijos en la figura de Cristo Rey como esperando una respuesta. Bajo ella, en el extremo inferior izquierdo de la pintura, una pobre mujer desesperada levanta sus brazos al cielo, inmersa en la negrura de la tragedia (fig. I2). La Guadalupana es el espejo trascendente de su gesto.

Llama la atención que las banderas que portan los ángeles esta vez no son las de Latinoamérica, porque entre ellas se distinguen perfectamente las enseñas francesa, cubana e inglesa: las naciones que apoyaron a la Iglesia mexicana en aquellos momentos de persecución. La bandera británica, muy evidente, parece hacer referencia a la relación establecida con el rey de Inglaterra por el entonces obispo de Huejutla, monseñor José de Jesús Manríquez y Zárate, quien había sido perseguido y expulsado de México cuando se inconformó con el gobierno en una carta pastoral donde denunciaba las acciones que el gobernador de Tabasco, Tomás Garrido Canabal, implementó al amparo de la Constitución: la prohibición a los sacerdotes extranjeros para oficiar y el decreto que obligaba a los sacerdotes nacionales a casarse para conservar el permiso de oficiar. A los once meses de encierro, el obispo de Huejutla fue liberado bajo fianza y envia- 


\section{I36} MARGARITA HANHAUSEN COLE

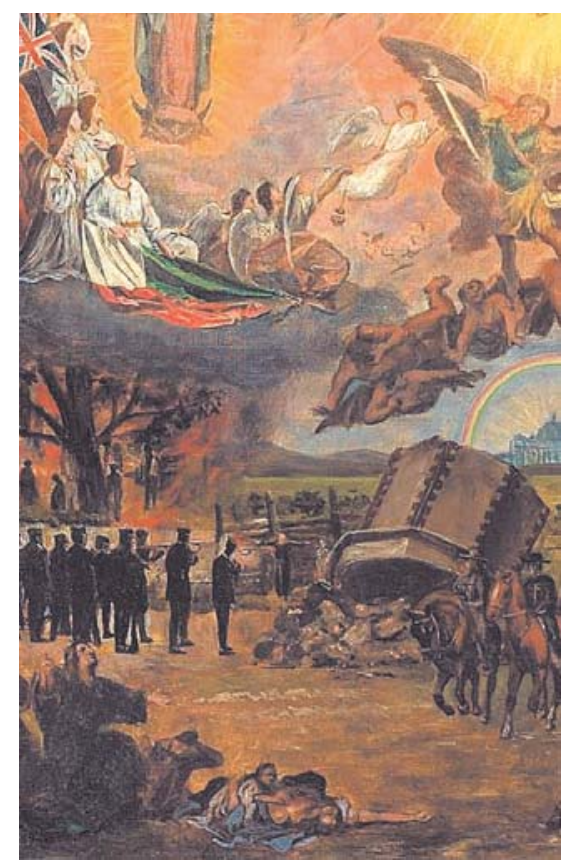

I2. Gonzalo Carrasco, El triunfo de Cristo Rey, óleo sobre tela, sin fecha o firma. Detalle de la damnificada suplicante, tomado de Margarita Hanhausen et al., La pintura y la palabra. Dos artistas jesuitas mexicanos: Gonzalo Carrasco y Miguel Aguayo, México, Universidad Iberoamericana/Fundación Bustos Barrena SJ, 2005, p. 25.

do al exilio. En ese tiempo recibió una favorable acogida por parte del monarca británico. ${ }^{23}$

El cuadro de la Iglesia triunfante se completa con las legiones de ángeles, al estilo de las ilustraciones de Doré para el Paraíso perdido de Milton, escoltando a la Virgen, adorando a la Cruz y a Cristo Rey y combatiendo a los demonios.

23. Cfr. Jean Meyer, La Cristiada, México, Siglo XXI, 1979, vol. I, pp. 316-320. Monseñor José de Jesús Manríquez y Zárate, nacido en León, Guanajuato el 7 de noviembre de 1884, fue nombrado primer obispo de Huejutla el II de diciembre de I922. Su destierro lo pasó primeramente en San Antonio, Texas, después en La Habana y posteriormente en España. Dado que no podía regresar a México, renunció a la diócesis el I de julio de 1939. Finalmente pudo regresar a México a finales de la década de 1940 y murió en la ciudad de México el 28 de junio de 195I. Algunos datos interesantes sobre él se encuentran en el libro de David Brading, Mexican Phoenix: Our Lady of Guadalupe, Image and Tradition through Five Centuries, Cambridge University Press, 200I. La presencia del súbdito británico Graham Greene en México, en esas décadas, y su interés por el tema de la represión religiosa en Tabasco que quedó plasmado en la novela El poder y la gloria (1940) pudiera explicarse por este motivo. 


\title{
La homilia pintada
}

La postura personal de Carrasco ante los acontecimientos fue obediente a lo que la jerarquía católica había oficialmente dispuesto al principio del conflicto, respecto a mantener una posición defensiva, aunque en modo alguno partidaria de que los católicos —y menos aún, que los sacerdotes — tomaran las armas contra el gobierno. Sin embargo, cuando el movimiento cobró fuerza, esa misma jerarquía lo bendijo más o menos abiertamente. ${ }^{24}$ En sus escritos Carrasco manifiesta confiar en que la victoria se obtendría gracias a la intervención trascendente como respuesta a la oración y a una vida virtuosa de los católicos mexicanos:

\author{
Unos confían en sus carros, \\ otros en su caballería; \\ nosotros invocamos el nombre \\ del Señor, Dios nuestro. ${ }^{25}$
}

Sin embargo Carrasco no se mostró ciego a la realidad. En el plano terrenal de El triunfo de Cristo Rey, las escenas del ángulo inferior izquierdo, mostrando los sufrimientos de la Iglesia paciente, son sobrecogedoras. Toda esa parte representa destrucción y muerte, sin apelación posible. En primer plano, con el escorzo de una mujer muerta a la que se abraza una niña, Carrasco subraya el estado de atropello contra los más débiles. ${ }^{26}$

Para el gobierno callista, la oscuridad y la barbarie estaban del lado del clero y los católicos. La perspectiva que ofrece la historia del periodo subraya la necesidad de una reorganización laica de la sociedad mexicana en aras de la superación del atraso educativo y cultural, pero también la existencia de un diálogo

24. En febrero de 1927, monseñor José María González y Valencia lanzaba, en Roma, su famosa carta pastoral a los católicos de su arquidiócesis: "Nos nunca provocamos este movimiento armado. Pero una vez que, agotados todos los medios pacíficos, ese movimiento existe, a nuestros hijos católicos que anden levantados en armas por la defensa de sus derechos sociales y religiosos, después de haberlo pensado largamente ante Dios y de haber consultado a los teólogos más sabios de la ciudad de Roma, debemos decirles: Estad tranquilos en vuestras conciencias y recibid nuestras bendiciones". Esta carta pastoral no llegó jamás a los cristeros aislados en sus montañas, pero no tenían necesidad de ella para convencerse de que peleaban una causa justa”. Cfr. La Cristiada en www.clerus.org/clerus/dati/2006-06/IO-I3/soto.html

25. Salmo i9.

26. Véase el detalle correspondiente a la Matanza de Chios (I821-1824) de Eugène Delacroix (I798-1863), tal vez una posible fuente de inspiración de los típicos desastres de toda guerra. 
de sordos que resultó en la polarización irreconciliable de ambas posiciones. El clero esperaba que el presidente Calles actuara al igual que el presidente Díaz había hecho, disimulando las leyes contrarias a la Iglesia, a lo que Calles no estaba dispuesto. De esta falta de comunicación devino la cristiada, que sumiría a México en tres sangrientos años de guerra civil.

El tercio vertical izquierdo de la pintura, realizado en un registro de rojos quemados y tierras que se oscurecen hasta los tonos pardos más apagados, muestra el sufrimiento padecido: los ahorcados, el fusilado, los damnificados por la guerra y el pedestal demolido, reciben la acción violenta de quienes ostentan en ese momento el poder de humillarlos. En la parte superior de ese tercio, en el plano celeste, la Guadalupana muestra otro registro de pasividad, ya que a la altura de esas circunstancias solamente puede hacer una labor de intercesión. Poner remedio será trabajo de su Hijo, quien nada negará a su Madre. La visión del jesuita pintor es en este momento distinta de la visión popular, en la cual la Guadalupana es presentada en multitud de exvotos como fuente autónoma de poder.

En el centro de la composición, la actividad de la Iglesia militante se representa con colores más vivos y variados. Bajo Cristo Rey, san Miguel arcángel (una cita de la pintura de Guido Reni, conservada en la iglesia de las Capuchinas de Roma, que con anterioridad Carrasco ya había reproducido en el ábside de la Sagrada Familia) lucha contra una hueste de demonios. Hay un llamado implícito a tomar partido por la causa de la Guadalupana y Cristo Rey, como se exhorta en la primera estrofa del himno guadalupano.

$$
\begin{aligned}
& \text { Mexicanos: volad presurosos } \\
& \text { del pendón de la Virgen en pos, } \\
& \text { y en la lucha saldréis victoriosos, } \\
& \text { defendiendo a la Patria y a Dios. }{ }^{27}
\end{aligned}
$$

Bajo este registro celeste, en el plano terrenal, un ejército marcha con la bandera blanca de la religión. Si se comparan los caballos de esta pintura con el brioso corcel negro de Iturbide en El éxtasis del libertador (fig. I3), se verá que dibujar la silueta de este animal no era el fuerte de Carrasco, ya que la rigidez de la pose los hace parecer de utilería y su representación no resulta convincente. El líder a la cabeza del destacamento de caballería guarda mucho parecido con el general 
13. Gonzalo Carrasco, El éxtasis del libertador, 1924, óleo sobre tela, tomada de Renato González Mello et al., Los pinceles de la Historia IV: la arqueología del régimen I9I0-I955,

México, Museo Nacional de Arte/Consejo Nacional para la Cultura y las Artes/Universidad Nacional Autónoma de México-

Instituto de Investigaciones Estéticas, 2003, p. 71. Colección particular.
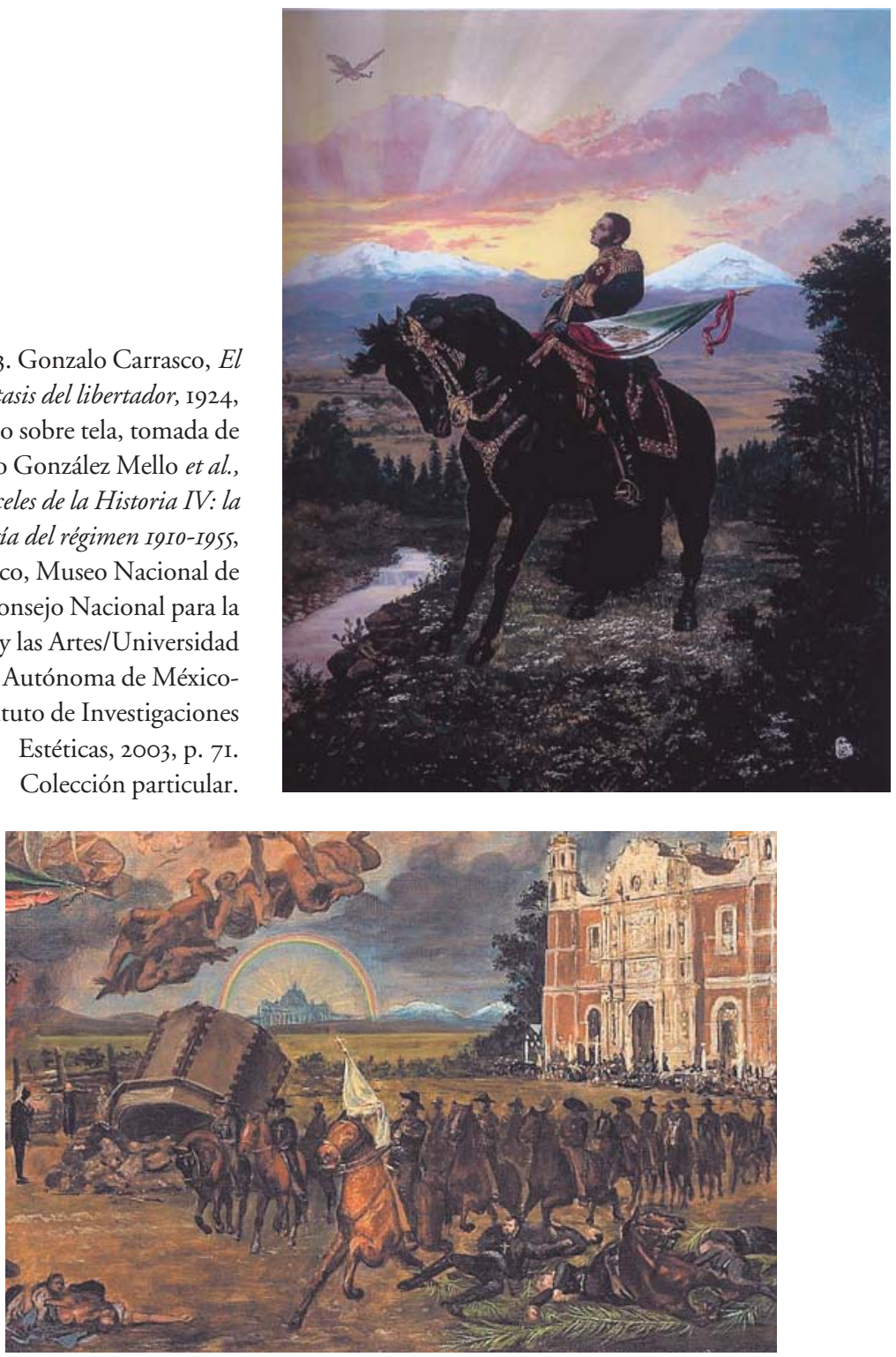

I4. Gonzalo Carrasco, El triunfo de Cristo Rey. Detalle de la caballería del general Gorostieta, tomado del libro de Margarita Hanhausen et al., La pintura y la palabra... México, Universidad Iberoamericana/Fundación Bustos Barrena SJ, 2005, p. 25. 
cristero Enrique Gorostieta, con su característico sombrero y el enorme crucifijo al pecho. Entran a la pintura en una diagonal desde el fondo de la Basílica de Guadalupe, representada con las puertas cerradas y con una muchedumbre agolpada frente a ellas (fig. I4).

No es tema de este artículo el detallar los pormenores de este periodo de la historia de México más allá de lo indispensable para ayudar a comprender el tema del boceto analizado. Fue un conflicto de intransigencias entre el gobierno mexicano y la Iglesia, donde esta última pretendía un imposible en esas circunstancias: que, como queda dicho, el gobierno del general Calles se comportara con la Iglesia como lo había hecho en su momento el gobierno del general Porfirio Díaz. A eso se sumaba que los laicos católicos pretendían mayores espacios de participación política para su movimiento. Por parte del gobierno la postura estaba fijada: las leyes que restringían el culto público y la participación de la Iglesia en la educación no iban a ser derogadas ni solapado su incumplimiento. El problema pudo haberse controlado con mucha prudencia y extremo realismo, cualidades al parecer inexistentes en las personas encargadas de la negociación entre ambos grupos.

La respuesta de la Iglesia ante la negativa del gobierno a ceder a sus pretensiones fue poner a México en estado de interdicción, suspendiendo la impartición de sacramentos y decretando el cierre de los templos al culto. Por si fuera poco, hicieron un llamado a los católicos a oponerse al gobierno, en principio en forma de boicot y de resistencia pacífica, pero que muchos lo interpretaron como el llamado a tomar las armas en una guerra santa.

En el extremo inferior derecho hay cinco muertos y un caballo malherido. Van vestidos con sotanas cortas, la banda a la cintura, el crucifijo en el pecho y botas de montar, evidenciando la presencia sacerdotal en las filas del ejército cristero. Es una referencia a los cinco sacerdotes combatientes en los Altos de Jalisco. La épica muerte del padre Reyes Vega fue el hecho que contribuyó a datar este boceto en algún momento de ese año. ${ }^{28}$ Carrasco se tomó la libertad de

28. La clave para identificar estas figuritas fue el constatar que uno de estos muertos fue baleado junto con su caballo, haciendo referencia al padre José Reyes Vega, quien murió en la batalla de Tepatitlán, Jalisco, el I7 de marzo de 1929, a resultas de la carga que realizó a caballo contra un destacamento de tropa agrarista. Su caballo fue acribillado y le cayó encima. Al intentar levantarse, el jinete fue baleado. Encontré tan sólo breve mención de los padres Aristeo Pedroza, Pérez Aldape y José Reyes Vega, este último apodado por los gobiernistas como "El Pancho Villa con sotana" dada la ferocidad de sus tropas y la barbarie desplegada en el ataque perpetrado al tren de La Barca, Jalisco, en abril de 1927. Cfr. www.liceus.com/cgi-bin/ac/pu/crist6.asp y Gustavo Carrère Cadirant www.arbil.org/9repop.htm 
mostrarles su simpatía y legitimar plásticamente su causa al otorgarles las palmas del martirio, que para los católicos es considerado causa expedita de santidad. Aunque la historia cuenta que estos cinco sacerdotes no murieron en la misma acción militar, Carrasco los representa unidos en el concepto del martirio y, a diferencia de los caídos del extremo izquierdo, no los llevaron al matadero: la muerte los sorprendió como rebeldes y vendieron cara su vida. Se enfrentaron al enemigo, tanto desde el púlpito como con las armas en la mano.

El enemigo salió raspado de esta batalla contra fanáticos que se preparaban para el martirio como tratándose de una purificación personal, como lo evidencia esta oración compuesta por Anacleto González Flores:

¡Jesús misericordioso! Mis pecados son más que las gotas de sangre que derramaste por mí. No merezco pertenecer al ejército que defiende los derechos de tu Iglesia y que lucha por ti. Quisiera nunca haber pecado para que mi vida fuera una ofrenda agradable a tus ojos. Lávame de mis iniquidades y límpiame de mis pecados. Por tu santa Cruz, por mi Madre Santísima de Guadalupe, perdóname, no he sabido hacer penitencia de mis pecados; por eso quiero recibir la muerte como un castigo merecido por ellos. No quiero pelear, ni vivir, ni morir, sino por ti y por tu Iglesia. ¡Madre Santa de Guadalupe!, acompaña en su agonía a este pobre pecador. Concédeme que mi último grito en la tierra y mi primer cántico en el Cielo sea ¡Viva Cristo Rey! ${ }^{29}$

Independientemente de la anécdota de los episodios de la lucha cristera, el mensaje contenido en esta oración no deja de sacudir la sensibilidad del hombre contemporáneo, ya que el fanatismo religioso de todo signo aún no ha podido ser erradicado a principios del siglo XXI.

Dos figuras representadas en el plano terrenal fijan su mirada en lo alto en medio de esa batalla cósmica: la mujer del lado izquierdo, cuyo gesto imita al de la Virgen y el líder cristero, portando la bandera, para mayor identificación con el Iturbide de la figura I3. Ambas efigies, representando la pasividad femenina y la acción masculina, tienen la vista puesta en la Guadalupana suplicante, vértice del triángulo formado por estas tres figuras. Otro triángulo invertido converge en la imagen del líder cristero, teniendo en su base la interacción de

29. Esta oración, compuesta por el líder de la Asociación Católica de Jóvenes Mexicanos (ACJM), Anacleto González Flores, era rezada por los católicos de Jalisco al final del Santo Rosario. Cfr. Jean Meyer, op. cit., vol. III, p. 280 e Identidad Católica: Galería Gráfica sobre los Cristeros en www. montfort.org.br/index.php?secao=oracoes\&subsecao $=$ diversas\&artigo $=$ cristeros\&lang=esp 
la Guadalupana y san Miguel arcángel quien, guardando las jerarquías, aparece como general de los ejércitos de Jesucristo, patrono y protector de la Iglesia universal contra las huestes de Satán. En el primer triángulo se muestra una perspectiva de oración desde el plano terreno al celestial y en el segundo se hace patente la inspiración divina del caudillo, que parece estar haciendo un alto para constatar el patrocinio celeste de la causa que defiende. Un tercer triángulo muestra la relación entre Cristo Rey, el Vaticano y la Basílica de Guadalupe (fig. I5).

La escalada de violencia fue feroz por parte de uno y otro bando: en noviembre de 1927 el padre Pro y sus compañeros fueron fusilados, se recrudeció la persecución religiosa y, en enero de 1928, el monumento a Cristo Rey en el Cubilete fue bombardeado. Por si fuera poco, en julio de ese año, un católico fanático, presuntamente inspirado en el episodio de Judith y Holofernes del Antiguo Testamento, asesinó al presidente Obregón, recién reelecto, en el restaurante La bombilla del barrio de San Ángel en la ciudad de México.

La fachada de la Basílica de Guadalupe, al lado derecho, está en la misma posición que la de la parroquia de San Juan Bautista en Coyoacán, en una pintura de Carrasco con el tema del martirio de Luz Cirenia Camacho González (I907I934), una joven terciaria franciscana, que murió junto con otros cuatro fieles a manos de un grupo extremista anticatólico, en el exterior de aquella parroquia en diciembre de $1934 .{ }^{30} \mathrm{La}$ Basílica de Guadalupe aún aparece clausurada, antes de "los arreglos" de 1930 con los que la jerarquía eclesiástica pondría fin al conflicto que se prolongó durante cuatro largos años. A las puertas cerradas se agolpa una muchedumbre que protesta y resiste pacíficamente. Conforme al discurso plástico de Carrasco, el que el máximo santuario mariano de México haya quedado sin culto no fue obstáculo para que las presencias trascendentes, veneradas en él, salieran al exterior a luchar junto a sus devotos por una definición de sociedad.

Finalmente el gobierno mexicano y la Iglesia pactaron el fin de las hostilidades, en condiciones que no satisficieron a muchos de los cristeros que habían combatido por el triunfo de la causa católica. El episodio de los mártires de Coyoacán en 1934 demostró que la situación distaba de ser ideal para los católicos mexicanos, a cuatro años escasos del fin de las hostilidades.

30. En 2002 Renato González Mello me mostró una fotografía en blanco y negro de la pintura que Gonzalo Carrasco hizo de El martirio de Luz Camacho, pintada en 1934. Comentó que Jaime Cuadriello conocía al hermano menor de la infortunada muchacha, actualmente dueño y celoso guardián del cuadro. Para más detalles de las circunstancias de su martirio $\mathrm{c} f$ r. Arzobispado de México: causas de beatificación y canonización introducidas en Fase Romana, en www.arzobispadomexico.org.mx. 
15. Gonzalo Carrasco, El triunfo de Cristo Rey, óleo sobre tela, sin fecha o firma. Imagen, con líneas sugeridas de lectura, tomada de Margarita Hanhausen et al., La pintura y la palabra. Dos artistas jesuitas mexicanos: Gonzalo Carrasco y Miguel Aguayo, México, Universidad Iberoamericana/Fundación Bustos Barrena SJ, 2005, p. 25.

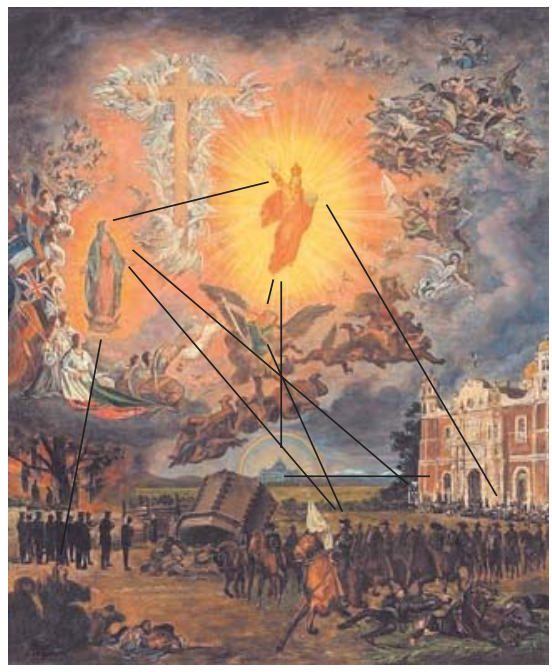

Llama la atención el binomio formado por el pedestal en ruinas del monumento del Cubilete y la figura de Cristo Rey. Aparte de la representación literal del suceso, Cristo Rey parece trascender su propio monumento, a la manera que el sepulcro es abandonado en las imágenes tradicionales de la Resurrección. Carrasco deja en evidencia que ese acto de barbarie no fue eficaz en cuanto a menguar el poder de Cristo Rey. El basamento construido como el remate de un torreón octogonal militar de finales del siglo XIX, con las esquinas reforzadas, es una obra material y como tal, susceptible de ser destruida. Pero el poder que representa, no.

Una de las lecturas del episodio puede ser hecha, desde nuestra óptica contemporánea, como esa iconoclasia que termina apuntalando firmemente las imágenes que pretende destruir. En su momento, la destrucción brutal de un símbolo para los católicos mexicanos fue evaluada negativamente como una derrota. Pero la imagen destruida tiene el poder de hacerse eterna, como la sangre de los mártires es garantía de la pervivencia de su causa: los católicos mexicanos no cejaron en la defensa de sus ideales y hoy otro monumento, más imponente que el destruido, corona el cerro del Cubilete, centro geográfico de la república mexicana desde donde Cristo Rey preside simbólicamente el corazón de México. ${ }^{3 \mathrm{I}}$

3I. Valentina Torres Septién, "De cerro a montaña santa: la construcción del monumento a Cristo Rey (1919-1960)", Historia y Grafia, México, Universidad Iberoamericana, núm. 22, julio de 2004, pp. II3-I53. 
Atrás de esta ruina y al lado de los volcanes que ubican la escena en el valle de México, Carrasco hace resaltar la silueta de la Basílica de San Pedro en el Vaticano como figurando el oriente de los mapas antiguos, fijado en Jerusalén, la ciudad de Dios. Como el Popocatépetl y el Iztaccíhuatl, inmutables custodios del valle de México, Roma, en El triunfo de Cristo Reyse muestra como una presencia lejana, poderosa y estable. La basílica vaticana aparece nimbada con el arco iris como el arca de la nueva alianza. Hay que recordar que el pintor es un jesuita que ha pronunciado el cuarto voto de obediencia al Papa, convencido de que "fuera de la Iglesia no existe salvación" 32 y que para él el pacto de la Resurrección es vigente en la nave de san Pedro; tan sólida, eterna y permanente como las montañas, "de donde vendrá la salvación". ${ }^{33}$ Como el lienzo tricolor del costurero de la Virgen en La Sagrada Familia de Rafael Flores, Carrasco señala con símbolos de fácil lectura la ubicación de semejante drama cósmico en tierra mexicana.

\section{La fuerza de la tradición, la sutileza de la modernidad}

En el aspecto formal, El triunfo de Cristo Rey es una imagen que intriga. La mezcla del plano divino y el cotidiano hace pensar en un exvoto, sin embargo, no representa la historia de un favor recibido o de una catástrofe evitada, sino la instantánea de una lucha apocalíptica. Los exvotos son, por lo general, trabajos terminados en pequeño formato y este boceto parece haber sido el proyecto de algo más ambicioso.

Desde la década de los años veinte se empezaron a construir edificios de estilo neocolonial en varias ciudades de México. Fue un afán nacionalista, que reinterpretaba la tradición identificada con lo vernáculo, a diferencia de los toques cosmopolitas del Art Decó y del naciente funcionalismo. Las construcciones tanto públicas como privadas ostentaron detalles de talavera, así como elementos de ornamentación dieciochesca. ${ }^{34}$ En esas circunstancias, la composición de El triunfo de Cristo Rey, recordando una obra del tiempo novohispano, no sería

32. Faltaban más de 30 años para que el Concilio Vaticano II matizara este postulado, vigente en tiempos de Carrasco y columna del fanatismo católico de todos los tiempos que entiende únicamente por "Iglesia" la Romana, Católica y Apostólica.

33. Salmo I2r: "Alzaré mis ojos a los montes, de donde vendrá mi salvación”.

34. Jorge Alberto Manrique, “Arquitectura Mexicana I890-1980", en Una visión del Arte y de la Historia, México, Universidad Autónoma de México-Instituto de Investigaciones Estéticas, 200I, vol. 5, pp. 68-70. 
casual. Hay en este boceto varios elementos formales que hacen recordar una pintura popular con cierto sabor del barroco tardío. Pero de la misma manera que los detalles ornamentales de cantera de las mansiones de Polanco jamás serían confundidas con obras del barroco mexicano, esta pintura adolece de ciertas concesiones a la modernidad, mismas que Carrasco incluyó posiblemente sin darse cuenta, tales como el colorido, el recurso de las citas a manera de montaje fotoperiodístico y el tono general de la obra.

Carrasco se resistió a renovarse en su lenguaje plástico, rechazando los elementos más atrevidos de las vanguardias, sin embargo, en las pinturas de los últimos años, hay concesiones a "algo" que a fuerza de separarse de la estricta observancia del canon formal aprendido en la Escuela de Bellas Artes, adoptando recursos de la ilustración gráfica y el fotoperiodismo, tiene que ser calificado como "nuevo". Como muchos pintores de su generación, Carrasco vio en las vanguardias un retroceso, evaluando, desde la perspectiva académica, la distorsión arbitraria de la realidad mediante el uso del color y la alteración de las proporciones. Pero una cosa es pintar una alegoría en los siglos XVII y XVIII y otra muy distinta es hacer una pintura anacrónica, contemporánea a la revolución mexicana, a la consolidación de la revolución soviética, al New Deal de Roosevelt y al ascenso de los totalitarismos fascistas, haciendo interactuar dos planos de realidad en el mismo tiempo y espacio. Hoy, esa visión real maravillosa de la lucha entre dos fanatismos, el estatista y el católico, ya no puede ser vista con la misma perspectiva con la que vemos mezclarse los planos terreno y celeste en las obras novohispanas.

Independientemente de que el espectador de esta pintura comparta su pensamiento, Carrasco presenta a los católicos mexicanos como héroes, pese a su vulnerabilidad, y se contenta con evidenciar los estragos causados por sus enemigos, sin concederles a éstos el derecho de preservar sus rostros. Fue la circunstancial encarnación del "mal" mero instrumento para darles a los católicos caídos la palma del martirio y la entrada a la Gloria.

Carrasco, escribió en vísperas del alzamiento cristero:

No triunfaremos con ametralladoras, ni con dineros y combinaciones políticas; sino con la paciencia, con el amor cristiano, con la virtud que resucitó a Cristo. ${ }^{35}$

35. Gómez Robledo, op cit., p. 278. Independientemente de que esto no haya sucedido, es lo que Carrasco pensaba. Al parecer se trata de un escrito de 1925 . 
Pero la actuación de la Providencia operó a través de los seres humanos. A la llegada a México, en 1927, del embajador de los Estados Unidos, Dwight W. Morrow, su opinión fue que era necesario llegar a un arreglo, ya que el país estaba totalmente trastornado y la Iglesia, fuera o no el bastión del oscurantismo, el apoyo del atraso y la reacción a ojos del gobierno, para la mayoría del pueblo mexicano era una institución fundamental, por lo que enemistarse con ella equivalía a arriesgarse a una guerra civil interminable. Entre 1927 y 1928, Morrow concertó varias entrevistas entre el presidente Calles y sacerdotes norteamericanos amigos suyos que pudieron hacerle entender el problema y su necesidad de pronta solución, sin menoscabo de los intereses del Estado mexicano. El asesinato del general Obregón retrasó la posibilidad de establecer tales arreglos.

Carrasco pasó los últimos años de su vida en un México muy distinto al que había conocido en su infancia y juventud. I934 y 1935 fueron años en que la secularización liberal poco a poco tomó una faceta socialista que les parecía todavía más amenazadora a los católicos conservadores. El papa Pío XI había hecho la consagración de la humanidad a Cristo Rey en las conflictivas décadas de los años veinte, presentando a la Iglesia Católica Romana como la representante de ese Rey Eterno, perseguida en la tierra. ${ }^{36}$ Para Carrasco la sociedad mexicana iba directamente por el camino de la pérdida de valores morales y religiosos, hasta naufragar en el secularismo ateo. Su testimonio plástico, plasmado en este boceto, bien pudo ser la afirmación de la condición de posibilidad de un motivo de esperanza y de sentido.

Carrasco tenía cerca de setenta años cuando pintó El triunfo de Cristo Rey. Sus escritos y biografía lo muestran más preocupado en ocupar su tiempo impartiendo los sacramentos y oficiando con toda unción sus misas en esos tiempos difíciles que dando seguimiento a la lucha armada. No dejó de enterarse de todo cuanto sucedía, encomendándose al padre Pro, a quien unió en sus rezos con los santos de la Compañía. Cuando los tiempos se calmaron, Carrasco reanudó su trabajo en las misiones populares en el campo, hasta que su salud se lo impidió.

36. "Sed Rey de aquellos que, por seducción del error o por espíritu de discordia, viven separados de Vos; devolvedlos al puerto de la verdad y a la unidad de la fe para que en breve se forme un solo rebaño bajo un solo Pastor. [...] Conceded, ¡oh Señor!, incolumidad y libertad segura a vuestra Iglesia; otorgad a todos los pueblos la tranquilidad en el orden; haced que del uno al otro confín de la tierra no resuene sino ésta voz: ¡Alabado sea el Corazón divino, causa de nuestra salud! A Él se entonen cánticos de honor y de gloria por los siglos de los siglos”. Fragmento de la Consagración de la humanidad a Cristo Rey por el papa Pío XI, en www.ewtn.com/spanish/prayers/cristo_rey_consagracion_pioXI.htm 
El triunfo de Cristo Rey ofrece un atisbo de algo más personal del alma de ese sacerdote en los duros momentos de la persecución. Como ocurre en El Espiritu Santo Paráclito, tema del mural pintado en 1926 en la bóveda del ábside del templo del Espíritu Santo en Puebla, cuyos dones espirituales iluminan, protegen y fortalecen a la Iglesia jerárquica en la Tierra, las figuras de la Iglesia triunfante que pueblan los dos tercios superiores de este boceto muestran que, a pesar del horror, el sinsentido aparente y el combate, ese Cristo, "el Primero y el Último, el Viviente" 37 del Apocalipsis, terminará atrayendo hacia sí a la creación entera a través del duro camino purgativo de la historia.

En 1932 Carrasco sufrió un accidente de consideración que casi le costó la vida: se cayó del andamio en el Santuario de la Virgen de Guadalupe de León, Guanajuato, cuya bóveda estaba decorando junto con el hermano Tapia. No volvería a trabajar en una empresa semejante, limitándose en esos años a la pintura de caballete. En I935 su salud se agravó y murió a principios de 1936, recién cumplidos los 77 años. Fue sepultado en la cripta del templo del Espíritu Santo en Puebla.

Hasta el final de su vida Carrasco consideró que un artista plástico tenía que edificar a su público. Todavía al principio de la década de los años treinta, en pleno siglo xx, combatiría la opinión de Ignacio Manuel Altamirano, expresada en I883, sobre la necesidad de que los jóvenes artistas asumieran un compromiso con la nueva nación, prefiriendo los temas de la historia patria a los de la historia sagrada, como anticuados resabios de la plástica colonial..$^{38}$ Para Carrasco el tema religioso era y seguiría siendo vigente.

A pesar de su firme decisión de seguir produciendo una pintura en la línea de las directrices que sus maestros le trazaron a mediados de la era porfiriana, la elección de los temas de actualidad y la fantástica forma de representación de la presencia divina en medio de los sucesos de la historia contemporánea mexicana lo hicieron sintonizarse con su tiempo por primera vez en su trayectoria como pintor jesuita. Es así que, al final de su vida y por motivos pastorales en tiempos de persecución, estas dos obras, el mural del ábside del templo del Espíritu Santo, pero sobre todo, El triunfo de Cristo Rey fueron las únicas concesiones que hizo al pintar algo realmente "moderno". \$

37. Apoc. I, I2-I3, I7-I8, "Vi siete candelabros de oro, y en el medio de ellos, a alguien semejante a un Hijo de hombre [...] Al ver esto, caí a sus pies, como muerto, pero él, tocándome con su mano derecha, me dijo: "No temas: yo soy el Primero y el Último, el Viviente. Estuve muerto, pero ahora vivo para siempre y tengo la llave de la Muerte y del Abismo".

38. Ida Rodríguez Prampolini, La crítica de arte en México en el siglo XIX, México, Universidad Autónoma de México-Instituto de Investigaciones Estéticas, 1964, t. III. 